UDK 316.75:929Vode A.:929Šentjurc I. UDK 821.112.2(=163.6)-31.09Šentjurc I.

\title{
THE ORIGINS AND IMPACT OF STATE FORCE: THE CASES OF ANGELA VODE AND IGOR ŠENTJURC
}

\author{
Mira Miladinović Zalaznik
}

\begin{abstract}
Working without a theoretical background the article discusses two Slovenian intellectuals: Angela Vode and Igor Šentjurc. These two writers and publicists, though separated by sex and the centuries in which they were born, are bound by life experience, for the state and Party, along with its subordinates, the Secret Police (Geheim-Polizei), as well as legal authorities that oppressed them, were fundamentally and continually a part of these two individuals' lives.
\end{abstract}

Key words: Angela Vode, Igor von Percha, Igor Šentjurc, Secret Police, Woman in Today's World, Dolores Ibárruri, General Valentín González - El Campesino, Edvard Kocbek, the novel Feuer und Schwert

When I returned from prison, the hardest thing for me was to avoid cars. This was a sort of phobia. If it signalled left, I was convinced it would go right, and vice-versa. If it didn't signal, I was convinced that it would turn left or right. I didn't expect it to watch out for me. I didn't dare cross the street, and I would wait. Even today this sometimes still occurs. This I brought with me from prison. Into my flesh and blood had come a fear of deception (Vode 2004, 226).

As Robert Musil might say, today I have a "foreshortened perspective" - I am perspektivisch verkürzt. Working without a theoretical background I will present two Slovenian intellectuals: Angela Vode and Igor Šentjurc. These two writers and publicists, though separated by sex and the centuries in which they were born, are bound by life experience, for the state and Party, along with its subordinates, the Secret Police (Geheim-Polizei), as well as legal authorities that oppressed them, were fundamentally and continually a part of these two individuals' lives. 


\section{ANGELA VODE (1892-1985)}

Angela Vode was born on January 5, 1892 into a family of railway workers in Ljubljana, the present capital of Slovenia. She was the youngest daughter. Despite her sex, her parents and older brothers and sisters encouraged her to get an education. She concluded her schooling with a diploma that qualified her to be a primary school teacher. Between 1912 and 1920 - that is, beginning already during the Habsburg Monarchy - she taught in various villages around Ljubljana, while also performing other duties that the village surroundings of the time required of educated individuals. She held antiAustrian and leftist pro-Yugoslavian political views, and because of this the authorities kept continual tabs on her. She enthusiastically greeted the fall of the Austro-Hungarian Monarchy and the birth of the Kingdom of Serbs, Croats and Slovenes. In 1919 she became employed as a clerk in a factory that manufactured cast iron products. She was active in the division of the Social Democratic Party of Slovenia, which today counts as the forerunner of the first communist organization in Slovenia. In 1921 she passed a specialist exam for teaching handicapped children and found work at a so-called "auxiliary school" (as they were known at the time). There she had a rewarding 25-year career and earned a reputation as a leading expert in her field. Her membership in the Communist Party dates from $1922{ }^{1}$ she was also involved in a movement that fought for the rights of women, becoming president of the Woman's Movement (for Slovenia), which was a part of the broader Feminist Alliance. She collected literature from this area, and wrote articles on the development of society and the position of women in society. In 1929 she took part in the world conference of feminists, and in 1930 she became president of the Slovene chapter of the Society of Teachers, while remaining active also in other expert societies. She wrote articles that were published in dailies and periodicals, and held lectures, often outside of Ljubljana, on politics, culture, and social welfare almost always from the viewpoint of discrimination against women or of their emancipation. In addition to her regular employment she was engaged in many larger projects. In 1934 she wrote and published the book Žena $v$ sedanjem svetu (Woman in Today's World), which is a meticulously researched historical, sociological and political study of the role of women in society and in the family, of women's economic dependence on men, and of the influence of war and politics on woman's life. Reviews were positive, and her books soon sold out. She began to research Nazism intensively, also with the help of the German books she would order. ${ }^{2}$ Among those which she read closely immediately upon publication was Hitler's Mein Kampf (1924), and she was thus among the first to recognize the dangers of National-Socialism. In 1935 she published the book Žena i fašizam (Woman and Fascism) in Serbo-Croatian, and in 1936, to mark the 25th anniversary of her school, she edited Pomen pomožnega šolstva in njegov razvoj v Jugoslaviji (The Importance of Auxiliary Education and its Development in Yugoslavia).

\footnotetext{
${ }^{1}$ The majority of the documents -57 of the numerous official documents that one receives in a lifetime - were taken from her when she was arrested, never to be returned. Some were destroyed, whereas others are preserved in the Archives of Slovenia; those that were not destroyed most probably in 1990 when the Secret Police, sensing the approach of the 1991 democratic changes in Slovenia, purged the lion's share of their archives. (Cf. Puhar, 380).

${ }^{2}$ In addition to her native Slovenian, Vode had mastered German, English, French, Italian, Serbo-Croatian and, to a lesser extent, Russian. She read both literature and specialist literature in those languages.
} 
She fought for the franchise of women, ${ }^{3}$ endeavoured to bring in progressive legislation in the areas of labour, family, social justice and - something especially advanced for her time - for the introduction of social changes that would lead to the right to abortion. Her book Spol in usoda (Sex and Destiny) appeared in 1938, meeting with much approval but also with hostile reviews, especially in the clerical press, which attacked not only her expertise but also her humanity.

Although Angela Vode was overtly left-wing and a communist, in her published writings she did not adopt an ideological position, and she did not disseminate communist propaganda; her writing was always intelligent, cultivated, clear, readable and, not least, well-grounded. She wrote nothing in haste, and her firm convictions were informed by research and studies, including empirical ones. In 1939 war was approaching, and Angela Vode called upon Slovenians to bind together. She started a petition which was signed by 67 women's organizations, along with 185 organizations of mixed membership. At this time she was cast out of the Communist Party for having spoken publicly in a manner disagreeable to her Party colleagues, and for having condemned the Molotov-Ribbentrop Pact because she believed that Stalin would betray Slovenians in the name of international communism - just as he had already betrayed his convictions. From that time until her death Vode was under constant surveillance not only by the authorities of the time - the Kingdom of Yugoslavia - but by Italians, Germans and the post-war Federal People's Republic of Yugoslavia and the Socialist Federal Republic of Yugoslavia (that is, primarily the Communist Party). After Yugoslavia was occupied on April 6, 1941, Vode organized aid for refugees. The Board of the Yugoslavian' Women's Alliance selected her to represent them at The Liberation Front, ${ }^{4}$ the organization for the struggle against the occupiers, which the Communists first established for the fight against imperialism - more precisely, against the English and the Americans. Not until the start of the war in Yugoslavia in April 1941 did they change their name to Osvobodilna Fronta (Liberation Front). After six months working for the Liberation Front, Vode became convinced that the Communists in Slovenia were carrying out red terror and she therefore distanced herself from this organization, choosing to continue her aid on a personal level. She worked with everyone, regardless of their political convictions: with the Red Cross, other organizations, and churches. She raised help for prisoners in the Italian and German camps, especially for the non-organized (i.e. not members of the Communist Party) and people with no family. When in 1942 the Italians began to imprison and murder hostages en masse she organized a petition against Mussolini and within a short time collected the signatures of 2000 women. The Communists were against solitary action and confiscated the petition, defaming Vode in the process. In 1943 the Italian police imprisoned her for a few weeks. Following the Italian capitulation in September 1943 the Germans took control of Ljubljana and sent Vode, who had been betrayed by her former Party colleagues, to the Ravensbrück concentration camp in 1944. After someone intervened on her behalf she was released at the end of the same year. When she returned to Ljubljana, she lost her job. She be-

\footnotetext{
${ }^{3}$ Women in Yugoslavia received the right to vote in 1945; in 1946 this right was written into the constitution.

${ }^{4}$ The Liberation Front was founded in late April 1941 to fight against occupation. It was composed of various groups, with various ideologies, but the Communist Party was the predominant faction; already during World War II this led to civil war in Slovenia.
} 
gan to write her memoirs about the German concentration camp, though the post-war authorities did not want to publish these; she depended on support of her sister, Ivanka Spindler, for her economic survival.

At the end of the war the red terror intensified, and the state began to carry out mass extermination of civilians, prisoners of war and refugees (cf. Vodušek Starič 1992). Vode had to make a statement to OZNA (the Department for the Protection of the Nation $)^{5}$ about her internment at Ravensbrück and about her political past. In September 1945 she became employed at a school for children with special needs, though as one stigmatized by the Party she was unable to hold a permanent position - this in spite of the lack of educated individuals. On May 51947 (which was two days before Tito's birthday), UDBA, ${ }^{6}$ after two years of terror exercised on its own nation, arrested some 30 renowned intellectuals who were regarded as sympathetic to Western-style democracy. Among these, along with Angela Vode, were Partisans. She was interrogated under inhuman conditions for two months, always at night; during the day she was not allowed to sit or lie down, let alone sleep. The Politburo of the Communist Party of Slovenia determined that all of these alleged Anglo-American spies, enemies of the people, traitors, individuals friendly to the Gestapo, and saboteurs had to be made example of before they "succeeded in destroying 'socialist gains' in 'a free homeland"'(Vode 2004, 131). Fifteen people were put on trial and on July 29 the "Nagode trial" began (named after the first individual accused). On August 12, 1947 they each received extreme sentences; they were condemned to forced labour and they were stripped of their civil rights and liberties. Three were sentenced to death: Nagode was killed, ${ }^{7}$ while two of the accused "committed suicide" in prison; two were pardoned, including Dr. Ljubo Sirc (1920), ${ }^{8}$ who, after eight years of prison - two in solitary confinement - is today a retired university professor in Glasgow. Angela Vode was sentenced to twenty years forced labour, which, after the death penalty, is the highest punishment, and taken to the women's prison of Begunje. There she had to toil away quarrying stones. She was 55 years old. Her sister and nephew were evicted from their apartment in the centre of Ljubljana and given 2 damp rooms - a renovated lavatory and storeroom - in a nationalized house on the outskirts of the city. ${ }^{9}$ In 1948, at the time of the Cominform, or Tito's dissension from Stalin, Vode was tried again. Although a sworn anti-Stalinist, she was denounced by a co-prisoner in a forced written statement which claimed she was loyal to Stalin. She spent June 24, 1948 until the first half of 1949 in solitary confinement. Her sister managed to have her moved to the women's prison Rajhenburg (renamed Brestanica in 1952), where she saw the sun for the first time in almost two years. It was here that she celebrated her $60^{\text {th }}$ birthday. Together with other political prisoners, including the Vien-

\footnotetext{
${ }^{5}$ OZNA was established during the war, in 1944.

${ }^{6}$ UDBA, the state security office, or the Yugoslavian Secret Police, had a role similar to that of the NKVD in the Soviet Union or the Stasi in the German Democratic Republic. It was formed in 1946, when OZNA was divided into a civilian and a military section. The civilian section was called UDBA, the military section KOS (Counter-Intelligence Service). KOS was re-named Organ bezbednosti (Security Organ), and in 1996 UDBA became Služba državne bezbednosti (The State Security Service).

${ }^{7}$ His mother felt guilty because they had extracted her son's diary from her, and, after this became the primary source of evidence against him, she committed suicide.

${ }^{8}$ Ljubo Sirc's Father Franjo, who was sentenced at the same time as his son, died in prison's hospital.

${ }^{9}$ Left without any means of survival, the 60-year-old owner of the house drowned himself.
} 
nese Hildegard Hahn (who was considered Jewish on account of her father), Vode was sentenced at the Diehl-Oswald trial to death by firing squad. This was then reduced to twenty years strict confinement, because she was alleged guilty for the death of 70,000 Jews. Her room had no window panes, and birds and rats nested there. Two inmates slept on the same straw mattress and covered with their own blankets, provided their relatives were able to furnish them with such. For sanitary needs they had buckets that they had to carry out and empty into the so-called lavatory (ibid., 184). They received their rations in a cauldron in the courtyard and ate on the ground, like dogs (ibid., 204), from their own dishes and with their own spoons. Vode recalled Ravensbrück almost nostalgically, since there every evening they had received a large piece of bread, a portion of margarine and a large slice of sausage (ibid., 226-227). In Rajhenburg they did piecemeal work, in three shifts so that the state would not have to support them (ibid., 181-182). Vode's sister tabled a number of requests, asked for an audience among highup Party leaders that had been "friends" of Vode, but was unsuccessful. She started collecting signatures in support of her sister's relatives and added this list of signatures to her entreaty. On January 1, 1953 Angela Vode was released from prison. On returning home, she longed most to sleep properly for the first time in six years. She was required to sign a statement confirming that she would never speak of her time in prison, and put on a midnight train to Ljubljana. When she arrived in the early morning, she could not go home immediately because the tram had not yet started and she was too weak to go on foot. In the waiting room of the train station she met several other released prisoners who were waiting for public transportation to start.

"An acquaintance from the office of the interior once told me, 'You and Sirc and Furlan ${ }^{10}$ were actually condemned to death. Your life may have been spared on account of some external circumstances, but your destiny cannot be changed" (ibid., 303). Once freed, Angela Vode became what one of her interrogators, Stane Runko (1917-1988), had promised she would become under his surveillance: a non-person. Extremely ill, suffering from asthma and a digestive illness that was a result of her harsh imprisonment, she found herself uninsured, pensionless, not allowed to work, and without anyone willing to publish anything that she wrote. Because of her relation to Angela, her sister received a miserly pension. Angela's nephew, who was not allowed to study medicine at the time of her imprisonment, emigrated via Austria to Australia, where he became a doctor. Completed isolated, visited by few friends but by many denouncers, Angela borrowed a typewriter - the one that had been confiscated from the sisters Vode had never been returned. She wrote a study of Nietzsche as well as a study of neglected youth, though to date neither has been published. In 1958, at the age of 66, she was granted civil rights, and became employed as a secretary, though from her many years of work experience they subtracted the twelve years she spent in prison. It was also at that time that her translation of Stefan Zweig's memoirs Die Welt von Gestern was anonymously published. She wrote a textbook for educating individuals with special needs, but, fearing that it would be pilfered from her and published under

${ }^{10}$ The Slovenian lawyer and philosopher of law Boris Furlan (1894-1957) was also active as a translator and as a liberal politician. During World War II he worked for Radio London as "London's Slovene voice". A former minister in the Tito-Šubašić coalition government, he was sentenced in 1947 at the Nagode trial. http://en.wikipedia.org/wiki/Boris Furlan (Accessed: January 19 2010). 
another name, she subsequently burned it. Thirty years of her work disappeared. In hopes of finally receiving a pension she tried to become a member of the section of the veteran's association Zveza Borcev for those interned during World War II, but she was prevented from doing so because the head of this section was none other than Stane Runko, her interrogator. At this time Mišo Praprotnik published an article in Borec (The Fighter) attacking her and denouncing her yet again (ibid., 296-297). In 1960 she finally became entitled to a pension in the amount of 12,000 dinars, of which only 4,900 was actually paid to her. On the encouragement of Erna Muser, her former colleague from the woman's movement, she wrote a study of the worker's movement for the Institute for the History of the Worker's Movement. She received very modest payment, and the two reviews, including one written by the historian Milica Kacin Wohinz (who still today remains highly esteemed), stated that her text was in fact un-publishable. In 1968 she secured a passport and travelled throughout Europe, also visiting Hildegard Hahn in Vienna. In 1970/71 she completed her memoirs and accounts of the persecution under Communism, complemented by a lucid reflection on the post-war period and an analysis of communist theory and practice. Her final entry was written after Tito's death in 1980. After the death of her sister in 1975 her co-prisoner Mojca Prinčič moved in with her. Angela Vode strengthened contact with her nephew Janez Spindler, and she lived for part of 1976 with him and his family in Ulm. In 1982, after forty years of silence, she spoke publicly for the first time: on the third programme of Radio Ljubljana there was a show about her, prepared by Rapa Šuklje; in 1984 Nova Revija, a journal for Dichten und Denken (writing and thinking), published an interview with her.

A few years before her death, Vode began to put her affairs in order. Some of her personal effects she destroyed, and the rest she left to the Slovenian School Museum in Ljubljana. She kept her memoirs up-to-date and concealed, and told her nephew to publish them, if possible, after her death. She sold off her books and most of her furniture. In spring of 1985 the 93-year-old "Angela Vode decided that she had lived long enough. She took leave of those closest to her, saw to her final concerns, and stopped eating. One month later she was dead" (Puhar 2004, 373). ${ }^{11}$

\section{IGOR VON PERCHA (1927-1996)}

"Ein Mann hat das Recht zu wissen, wie sein Vater gestorben ist [...]" (Šentjurc 1993, 156) - "A man has the right to know how his father died". These words might well have been uttered by Andrej Wajda before he set to work on his film about the Katyn massacre. It was at this location in Russia that the Soviet Major-General of the NKVD Vasili Blokhin (1895-1955) set to work with his helpers every night after 10 pm. Using a German Walter pistol and German ammunition, and dressed in a leather butcher's apron, a hood and gloves that reached to his shoulders in order to keep his uniform clean, in complete darkness and alone, Blokhin killed 300 people per night. In twenty-eight nights a single human liquidated 8,300 Polish officers - a unique event in civilization at that time and level. Among the dead was Andrej Wajda's father.

\footnotetext{
${ }^{11}$ Vode's gravestone indicates 1983 as the year of her death.
} 
But the sentence "a man has the right to know how his father died" was not uttered by Wajda. It was uttered by a writer better known among his German readership as Igor von Percha. This was not his real name, and the "von" does not indicate nobility. The author's pseudonym is a mimicking of the medieval German poets who were named after the places from which they hailed. And so it was that the author opted for Igor from Percha, as it was in Percha, Bavaria that he began a new life in 1953 (the same year in which Angela Vode was released from prison). Here the political prisoner and Slovenian writer and publicist Igor Šentjurc found himself.

Igor Šentjurc was born in Slovenj Gradec on January 31, 1927. In 1941 his father was sent to do forced labour in Germany, and his mother to Austria with the children. Šentjurc was drafted into the German army and sent to the front. He deserted and joined the Partisans. In 1947 (when Angela Vode was imprisoned) he had to carry out military service for one year. When he returned in 1948, the rift between Tito and Stalin had occurred. The situation in Yugoslavia had become radically more severe, and concentration camps had been established on Goli Otok in Croatia and in Strnišče / Sterntal in Slovenia (today Kidričevo by Ptuj). Šentjurc found out about grave examples of torture and the death of inmates and determined that there was an enormous gap between the theory and the practice of communism. He described his experiences of the time in Gebet für den Mörder (Prayer for an Assassin in the novel's English translation) (1958) (Vodeb 1963, 180-188), although the primary theme of that work is the 1956 Hungarian uprising against the Soviets.

In 1949, when he was 22 years old - Vode had just been moved to Rajhenburg - Šentjurc was working as a journalist and deputy editor-in-chief of the sport weekly Polet (Élan). Meanwhile, he was creating literary texts and publishing literary sketches in contemporary journals. In 1952 his extremely unconventional sketch "Eden proti trem" ("One Against Three") was published in the journal Novi svet (New World). Its main protagonist, a young liquidator, has to track and kill members of the Home Guard. He recognizes that he has to liquidate the enemy, as commanded, and in spite of everything he respects that the enemy is also fighting for his ideals, even while knowing that they will not succeed. For the protagonist, such idealism under such conditions would be impossible.

In 1952, when Vode was 60 years old, Šentjurc, became the 25-year-old editor-in-chief of the magazine PPP (Poletove podobe in povesti - "Polet's Images and Tales"), Polet's supplement. He did not publish sports but literary contributions, including contemporary Slovenian narratives, English and American novels in serial form, literary sketches, pieces on modern life, practical advice, articles on fashion, jokes, and caricatures. Here it was that the comic Miki Muster first saw the light of day, after there was a problem at customs when importing the Disney original.

Today some of Šentjurc's remaining contemporaries from PPP claim that the magazine was pulp-like, the first stirrings of the tabloid press in Slovenia. In my view, they do this out of ignorance. At the time a very popular bon mot on censorship cited a lack of paper and a corresponding need to limit the number of published pages. Yet Šentjurc was able in spite of censorship and other controlling elements to publish economic and political articles in $P P P$, reportages from undeveloped places in Slovenia that clearly showed that in seven years of the People's Democracy circumstances had 
not improved. These matters were not otherwise covered in the Slovenian press of the time. He also reported on circumstances abroad. And so on August 8, 1952 on the first page he published a long article entitled "Kdo je kriv" ("Who is Guilty"), which meticulously reported on the crimes of the Soviet authorities in Katyn, which had been discovered in 1943.

Šentjurc published the anonymous article "Life and Death in the Soviet Union. What Happened to the Fighters for Republican Spain in the Soviet Union. A Life Worse than Death". Here he wrote in detail about pilots of the Republican army who had fought against Franco, as well as children and Spanish Communist leaders who had emigrated to the Soviet Union. For as long as the Spanish Republican government could support them, all was well. When support ceased, many children of both sexes were left to prostitution and a life of crime; if they did not subjugate themselves to Stalin, the pilots were liquidated, along with the Spanish Communists. The author especially exposed the hypocritical and infamous role of the leading European Communists Ilija Ehrenburg, Palmiro Togliatti, and Dolores Ibárruri ("La Passionaria"). The information for this article, which is stylistically clearly one of Šentjurc's, was taken from a book that Šentjurc must have known; the book had been published in Paris in 1950 under the title Vida y muerte en la URSS (1939-1949) (Life and Death in the USSR (1939-1949). It was written by the Spanish fighter General Valentín González (1909-1983), El Campesino. In his work González reports on how 6,000 Spanish refugees were transported by ship to the Soviet Union, and on how during the Spanish Civil war itself 1,700 children and 102 teachers had also left for the Soviet Union. González saw that the NKDV had liquidated 4,600 Spanish immigrants, 22,000 Germans and 18,000 Czechoslovakians. It is not known how Šentjurc obtained this book. It is possible that he found the information in a German source that certain privileged individuals in Slovenia were allowed to read..$^{12}$

Among the most unlikely articles in $P P^{13}$ was "A Special Report on the Events in Berlin", which was related by telephone by "Our Special Correspondent Martin Pfeideler" (Pfeideler 1953, 1). ${ }^{14}$ The German journalist reported on the insurrection in the German Democratic Republic, which had started in East Berlin and spread at lightning speed throughout East Germany. The Slovenian editorial department did not add a word of commentary to the article, but merely informed their readership about the bloody events. The Slovene dailies did not describe this so exactly and vividly, and neither did they publish any photographs.

The consequence of such an editorial policy, which did not report on Party Congresses and other important matters of socialist daily life, was that readership rose remarkably. In one year circulation rocketed from 6 or 7,000 to over 120,000. The Party became attentive and decided to act. A magazine that moved in the direction of opposition had to be brought into line - this is spite of the "liberalization" that followed the establishing of concentration camps on Goli Otok or in Sterntal, political trials

\footnotetext{
${ }^{12}$ In a January 19, 2009 article in the newspaper Delo Mimi Podkrižnik wrote about the shocking fate of the more than 30,000 children who vanished between 1944 and 1954 under Franco; there is no mention in this article of the Spanish who disappeared in the Soviet Union.

13 The name of the publication changed constantly.

14 They received the photographs through the mail.
} 
organized and transmitted via loudspeaker urbi et orbi (such as the Nagode trial and the Dachau trial). The same had already occurred in 1951 when the politician and poet Edvard Kocbek (1904-1981), a former Partisan and fellow fighter of Tito, was retired at the age of 47 and banned from publishing for ten years (Cf: Miladinović Zalaznik 2006, 607-621).

In Šentjurc's case the Communist Party decided to interrupt $P P$, and this decision was supported by both its youth organization and the Association of Slovenian journalists. In addition to this, a major of the Secret Police hinted to Šentjurc that the matter would not end there. The situation became increasingly unbearable for the young editor, especially because at the same time they wanted to recruit him for a volunteer activity: spying. ${ }^{15}$ Šentjurc decided to accept the offer for a work trip abroad and, with a valid passport and 100 dollars in his pocket (Vodeb 1963, 184), he headed to West Germany. In Munich he asked for political asylum. On October 9, 1953 he is said to have sent his publisher a letter stating, "for various reasons - primarily political ones - I have decided not to return to Ljubljana in the foreseeable future. Today I asked the authorities here for political asylum" (T. B. 1953, 259). This statement was published in only one paper, in the second edition of Ljudska pravica - Borba (The People's Rights - The Fight) on October $10,1953 .{ }^{16}$ A certain T. B. accused Šentjurc, among other things, of incompetence and ignorance as well as of longing for the German soldiers with whom he had spent time during the war; these accusations appeared in the (otherwise non-existent) column "Letters from our Readers" in which a part of the former editor's letter was "reprinted" (ibid).

The next day, on October 16, PP appeared for the last time. The editor's name was no longer published, and no reason was given for the cessation of the magazine. Two days latter, two dailies simply published an advertisement announcing that on October 22, 1953 instead of $P P, T T$ - Tedenska Tribuna (Weekly Tribune) would commence. It was most evocative of $P P$, the difference being that the editor Šentjurc had been removed. Never again was he spoken of in public.

In Germany in 1954 Šentjurc received the status of political refugee as well as a passport for people without citizenship. He also found work in the editorial office of the illustrated Lies mit. It was at this time that he wrote his first novel, Der Teufel braucht Liebe (The Devil Needs Love) which had appeared previously in serial form in the Münchner Abendzeitung. From then on he lived with his family (five children as well as a sickly Slovenian daughter from his first marriage who lived with him for eight years after his former wife took her there) by Lake Starnberg, for the most part as a writer. Here and there he wrote articles for various magazines and work for television, and from 1958 on - at the encouragement of Hardy Krüger - occasionally worked in film (including the 1960 classic Bumerang). Between 1973 and 1986 he wrote nothing, occupying himself instead with fish farming. When the political situation in the Eastern Bloc began to change radically, he once again sat at his typewriter. He died in 1996, a few days before his $69^{\text {th }}$ birthday. His works have sold ten million copies and have been translated into English, French, Dutch, Portuguese, Hebrew, Finnish, Slovenian and Turkish. He did not live to see the publication of his first book in Slovenian, which was published in 2001.

\footnotetext{
${ }^{15}$ We know this today also from sources published at the time.

${ }^{16}$ Such was the official name of the Slovenian newspaper that had a communal editorial office with the Party newspaper Borba from Belgrade.
} 
Šentjurc wrote more than 30 novels in German. He published them under four names: Igor von Percha, Igor Georgew (a near translation into German of Šentjurc), Igor von Seberg (an allusion to the mountain pass Jezersko) and Igor Šentjurc. Some of his novels were published in the feuilletons of the newspapers and magazines Münchner Abendzeitung, Quick, Stern and Bunte Illustrierte..$^{17}$ He wrote fictional political and historical novels, mysteries, romances, and some lighter novels; they each have real, historically-verifiable backgrounds. After 1986 he devoted himself to his most ambitious plan: a cycle of ten novels on changing times. This cycle was to deal with the individual stories of members of a single over 100 years of European history, including both world wars. He was able to complete two novels in this cycle, but died while working on the third one. The story in the novel Feuer und Schwert (The Fire and the Sword) (1988) literally turns around the single sentence "a man has the right to know how his father died" (Śentjurc 1993, 156) and deals thematically with the assassination of Archduke Franz Ferdinand in Sarajevo as well as World War I on Montenegrin soil. In the second, Im Sturm (In the Storm) (1991) Šentjurc deals with the interwar years as well as the post-war years, especially with the Prussian-Polish struggles; in the third, the unfinished Vaters Land (Father's Land) (1997), which was printed after his death (and which also exists in Slovenian translation), he deals with the civil wars in Romania and Spain. The mother of the main protagonist Ilon Dragonescu, who is half-Slovenian, raises her son in the spirit of "srčna kultura" - heartfelt culture (it is also written in Slovenian in the German original).

Šentjurc's literary oeuvre is in two languages, Slovenian and German, and it encompasses his life experience, especially of World War II and the decades-long Cold War. The constants of his works are humanism, a hope in woman as the bearer of progressive ideas as well as social emancipation, terror and totalitarianism from both left and right that is aimed at (one's own) people, both at groups and individuals, as well as the work of intelligence and counter-intelligence services.

III.

How do things stand today with Angela Vode and Igor Šentjurc? They swam against the stream both as individuals and writers, and they were prepared to suffer greatly for their ideas. Most painful is the fact that later generations of compatriots continue to renounce them, press them into the subconscious, remain silent about them, or even use them for manipulative purposes. Between 1998 and 2000 Mirjam Milharčič Hladnik published Vode's collected works in three volumes. She included studies about Vode and her fate, but these studies have a foreshortened perspective. Vode's Skriti spomin (Concealed Memory) appeared in 2004 thanks to the efforts of Alenka Puhar, who added a thorough study of the times and the author. Ljubljana Television produced a film version of Concealed Memory, which the 2009 Festival of Slovenian Film did not want to accommodate because they argued it was a documentary film. The interroga-

\footnotetext{
${ }^{17} \mathrm{He}$ had contact with the Gruppe 47, the esteemed group of authors writing in German, especially with Ingeborg Bachmann (1926-1973), Hans Magnus Enzensberger (1929) and Hans Werner Richter (1908-1993), the intellectual father of this group.
} 
tors and politicians in this film are nameless, because the pressure of so-called "healthy forces" remains too strong, leaving authors in fear of consequences. The film's premiere and single public showing took place at the former concentration camp Rajhenburg/Brestanica, though it was later shown on television. The charges against Angela Vode and those condemned along with her were annulled in 1991.

Those of Šentjurc's contemporaries that are still living do not want to speak, generally arguing that they did not know him well, that he only published in the yellow press (which was not even allowed at that time), or that they are in ill health and have forgotten everything. Now he is almost never spoken of, and not even my generation is familiar with him. The Archives of Slovenia are still not prepared to show all of the documents, and they claim that these were destroyed. Only one of his books, the unfinished Vaters Land, has been translated into Slovenian.

The upshot of all of this: I am of the opinion that there is a need for Vergangenheitsbewältigung in Slovenia, beginning with the less glorious, in fact, shameful parts of our history. Both individual perpetrators and all illegal acts must be judged. We Slovenians are not unique, nor are we rich and mighty enough to conceal our own history in the name of the communist ideology we still so nonchalantly and often uncritically praise. It is time that we accept these two individuals, as well as many others not named here, as part of our culture and history, and allot them the place they deserve.

Translated by Jason Blake

University of Ljubljana, Slovenia

\section{WORKS CITED}

Miladinović Zalaznik, Mira. Heinrich Böll und Edvard Kocbek im Briefwechsel. Die Geschichte einer Freundschaft. (Heinrich Böll and Edvard Kocbek in Correspondence: The Story of a Friendship). Estudios Filologicos Alemanes, 2006, vol. 12, 607-621.

Pfeideler, Martin: "Posebna reportaža o berlinskih dogodkih." (A Special Report on the Events in Berlin). PP, 26. June 1953, Volume II, no. 26, 1.

Puhar, Alenka. "Spremna beseda. Prebudi se, Debora" (Commentary. Awaken, Debora). Vode, Angela. Skriti spomin (Concealed Memory). Ed. Alenka Puhar. Ljubljana: Nova Revija, 2004. 373-392.

Šentjurc, Igor. Feuer und Schwert (The Fire and the Sword). München: DTV, 1993

T. B.. S tem sramotnim dejanjem so pokazali svoj pravi obraz. (With this Shameful Act they Showed their True Face). Ljudska pravica - Borba, 15. October 1953, p. 259, $2^{\text {nd }}$ edition, 6.

Vode, Angela. Skriti spomin (Concealed Memory). Ed. Alenka Puhar. Ljubljana: Nova Revija, 2004 
Vodeb, Rafko: Srečanje na Lilijski poti. (Razgovor z Igorjem Šentjurcem) (An Encounter on the Path of Lilies. A Discussion with Igor Šentjurc). Meddobje, 1963, no. 3-4, 180-188.

Vodušek Starič, Jera. Prevzem oblasti 1944-1946 (Taking Over Power: 1944-1946). Ljubljana: Cankarjeva založba, 1992.

http://en.wikipedia.org/wiki/Boris_Furlan (Accessed: January 19 2010) 